\title{
Study of treatment outcome of patients of tuberculous cervical lymphedenopathy
}

\author{
Nisha Mathew*, Sunil Jadhav, Ashish Deshmukh, Hafiz Deshmukh, Shivprasad Kasat, Sandeep Dandin \\ From 2nd International Science Symposium on HIV and Infectious Diseases (HIV SCIENCE 2014) \\ Chennai, India. 30 January - 1 February 2014
}

\section{Background}

Tuberculosis lymphadenopathy is the most common form of extrapulmonary tuberculosis. The aim of the present study is to detect the duration of treatment required in patients with cervical lymphadenopathy.

\section{Methods}

The patients attending the Department of Pulmonary Medicine OPD with cervical lymphadenopathy were screened. Detailed history, clinical examination, USG neck, FNAC, Mantoux test, biopsy, and chest X ray frontal view were performed and anti tuberculosis treatment initiated.

\section{Results}

Total patients examined: 117 , in the age group 10-70 years (mean age 40). Females affected - 89 (76.07\%), Males - 28 (23.93\%). Most common age group affected $(\mathrm{M} / \mathrm{F}): 15-20$ years: 37 (31.63\%) patients. Biopsy was done in 73 patients (62.39\%). Patients received Category1ATT under RNTCP. After 6 months of therapy, 22 patients $(18.81 \%)$ stopped treatment in view of nonpalpable mass. Out of remaining 95 patients $(81.19 \%)$, 14 patients' (11.96\%) lymph node size increased with slow regression, 17 patients' (14.52\%) liquefaction and repeated aspiration was done, 57 patients' (48.72\%) lymph node size showed regression less than $50 \%$, 7 patients (5.98\%) came up with new group of lymph nodes with size gradually increased. For all 95 patients, therapy was extended (continuation phase) for 2-3 months. 7 patients received ATT for 12 months.

\section{Conclusion}

Extrapulmonary tuberculosis like tuberculous lymphadenopathy is benefited with extension of anti tuberculosis treatment.

Published: 27 May 2014

doi:10.1186/1471-2334-14-S3-P42

Cite this article as: Mathew et al:: Study of treatment outcome of patients of tuberculous cervical lymphedenopathy. BMC Infectious Diseases 2014 14(Suppl 3):P42.

* Correspondence: unninishamathewcm@gmail.com Mahatma Gandhi Mission's Medical College \& Hospital, N-6 CIDCO, Aurangabad, Maharashtra, India

Submit your next manuscript to BioMed Central and take full advantage of:

- Convenient online submission

- Thorough peer review

- No space constraints or color figure charges

- Immediate publication on acceptance

- Inclusion in PubMed, CAS, Scopus and Google Scholar

- Research which is freely available for redistribution

Submit your manuscript at www.biomedcentral.com/submit

\section{() Biomed Central}

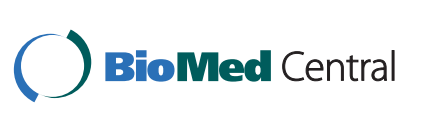

